\title{
Pre-service biology teacher's perception on local environment problems as contextual learning resources
}

\author{
Ahmad Yani ${ }^{1}$, Mohamad Amin ${ }^{2}$, Fatchur Rohman ${ }^{3}$, Endang Suarsini ${ }^{4}$, Muhammad Rijal ${ }^{5}$ \\ 1,2,3,4 Department of Biology, Faculty of Mathematics and Natural Sciences, Universitas Negeri Malang, Indonesia \\ ${ }^{1}$ Department of Biology Education, Faculty of Teacher Training and Education Science, Universitas \\ Puangrimaggalatung, South Sulawesi, Indonesia \\ ${ }^{5}$ Biology Education Program, Faculty of Teacher Training and Education, IAIN Ambon, Indonesia
}

\begin{tabular}{l}
\hline \hline Article Info \\
\hline Article history: \\
Received Nov 16, 2020 \\
Revised Jun 17, 2021 \\
Accepted Jul 14, 2021
\end{tabular}

Keywords:

Contextual learning

Lake Tempe

Learning outcome

Learning source

Pre-service biology teacher

\begin{abstract}
A survey and exploratory study were conducted to analyze Lake Tempe as a resource for contextual learning (CTL). The first phase of the study included exploring the lake's potential through interviews with the people who live in the lake's coastal region. Quadrat transects were done to identify aquatic plants around the lake. A feasibility analysis was conducted to see the lake's potential as a learning resource. Field data were collected and compared to the environmental biology (EB) curriculum, responses, and learning outcome. The data were analyzed descriptively and tested using a pairedsample t-test. The results showed differences in the three stations' physicochemical parameters and decreased quality of the water. It was found that anthropogenic activity had a significant contribution to the lake's pollution. Nine species of six aquatic plant families were found in the lake. The survey revealed that the lake was feasible as a learning resource with criteria easy to access, safety, time efficiency, costs, and the material's suitability for EB courses. The t-test showed a difference in the students' scores between before and after exploration practices. These findings suggest that Lake Tempe can serve as a resource for CTL in EB courses.
\end{abstract}

This is an open access article under the CC BY-SA license.

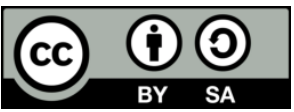

\section{Corresponding Author:}

Mohamad Amin

Department of Biology, Faculty of Mathematics and Natural Sciences

Universitas Negeri Malang

Malang, Indonesia

Email: mohamad.amin.fmipa@um.ac.id

\section{INTRODUCTION}

Current educational problems are becoming more complex [1], [2]. The root of the academic issues lies not far from the lack of students' awareness of learning, poor understanding of the concepts learned, and improper learning processes [3]. The development of different learning models and methods [4], teaching media [5], assessment techniques, and refinement of the curriculum at all educational levels continues to be carried out to overcome learning problems [6]-[9]. These efforts are made to improve the quality of education, especially in Indonesia. Besides, people are being equipped with skills and abilities to compete in the global world.

Globally competent people can examine local and global problems, understand worldview perspectives, interact and act responsibly for the common good [10], [11]. Therefore, undergraduate schools' learning process is carried out based on the Indonesian National Qualifications Framework (INQF). The learning outcomes specified in the INQF consist of interrelated knowledge, attitudes, and skills [12]. Students must be able to apply, study, design, leverage science and technology at the basic education level, and solve 
problems based on their respective areas of expertise [13]. Realized the demands of the INQF, it is necessary to choose and develop an appropriate learning approach, meaningful learning, and relevant teaching materials to support the learning process [14]-[16].

Relevant learning resources can support learning outcomes at all educational levels [17], [18]. In line with previous research [16], [19]-[21], learning resources need to be developed as they help students obtain information and data to improve learning effectiveness. Learning resources need to be suitable with students' characteristics [22], [23], nature of learning, classroom problems, and contexts of everyday life [24]. Learning resources should be compiled according to their users' needs, namely, the users' geographical, ethnographic, and regional-prosperity background. Besides, the selection of learning resources should be based on local potential [25], [26], and local problems [27], [28].

Discussing local problems in the classroom is a realization of contextual learning. Contextual learning allows students to build relationships in a more relevant and meaningful context. In contextual learning, lecturers can, for example, convert learning material into easily understandable learning content. In Biology, it is believed that the truth mainly lies in empirical evidence [29], [30]. Contextual learning can strengthen the teacher's role as a facilitator who guides students in constructing knowledge to become intelligent, creative, and innovative individuals, such as suggested by 21st-century education [31]-[34]. Hence, contextual learning is useful to improve students' ability to understand, prove, and uncover biological facts in the students' environment.

One of the frequently discussed topics on social media, television, and other communication media is pollution. In Indonesia, corrosion and environmental damage seem to get worse day by day. Pollution has directly threatened human life, which has terrible implications on nature, such as triggering natural disasters and diseases. Lake Tempe is an example of pollution phenomena that are happening in Indonesia. Lake Tempe, located in South Sulawesi, has been polluted by human anthropogenic activities that negatively impact the environment [35], [36]. Harmful substances have continuously contaminated the lake, so the water quality has been decreased significantly. Students as human successors are expected to recognize environmental problems and overcome ecological issues [24], [37]. Local such matters are highly relevant for students to learn, especially college or university students. Incorporating environmental issues into the classroom is key to the science learning process [38].

Academic units, especially universities, have not made optimal use of the natural environment as a resource for learning [39], [40], especially the local potential in their respective regions. Instructional materials and media merely cover issues in the school/campus environment, ignoring the local potential. While magazines, e-books, and international references can be used as learning resources, the pre-service biology teachers in a private university in South Sulawesi are only provided with textbooks and the Internet (blog and Wikipedia). They can learn the environmental issues through direct environmental observations [41], yet the university only allows them to understand concepts and theory. As a result, the students' academic achievement and learning outcome cannot improve accordingly.

A number of researchers have examined local potentials as a source of contextual learning [25], [26], [28], [40], [42], [43] through the development of monograph books [44]-[46], student activity sheets [28], [47], learning module [16], [48]-[51] and other types of instructional media [3], [52]-[54]. However, there is still little information available on students' perception of the local potential after conducting direct exploration activities on the study participants. Also, there are limited research reports that analyze the suitability between learning outcomes and facts obtained from contextual exploration results at the college level. The local potential can be utilized as a source of contextual learning through excursions. This study aimed to analyze Lake Tempe's potentials as a contextual learning source based on exploratory activities based on the description above. A feasibility study was conducted to examine the lake's potential as a resource for contextual learning by collecting students' answers and analyzing their academic achievement and cognitive learning outcomes.

\section{RESEARCH METHOD}

\subsection{Research model}

The current study consisted of two phases: a descriptive exploratory study and a feasibility survey. The first phase aimed to observe and explore the lake's potential through interviews with the community members who live in the lake's coastal region. In the second phase, a feasibility survey was conducted to examine the lake's potential as a learning resource based on historical facts that were later compared to the performance of the environmental biology students and the pre-service biology teachers' responses. The study was conducted in Lake Tempe, located in Wajo Regency, South Sulawesi, Indonesia as shown in Figure 1. 


\subsection{Participants}

There were two categories of participants in this study, namely society, and pre-service biology teachers. A group of local community members was invited for an interview. The interview was conducted to obtain information about potential and people activities that can reduce Lake Tempe water quality. The interview participants were selected using the purposive sampling technique based on the intensity of community activities. There were 150 local people live in the lake's coastal area participating in the interview. Meanwhile, the feasibility survey was conducted on 32 pre-service biology teachers (17 women and 15 men) who were enrolled in the environmental biology course at Puangrimaggalatung University, South Sulawesi.

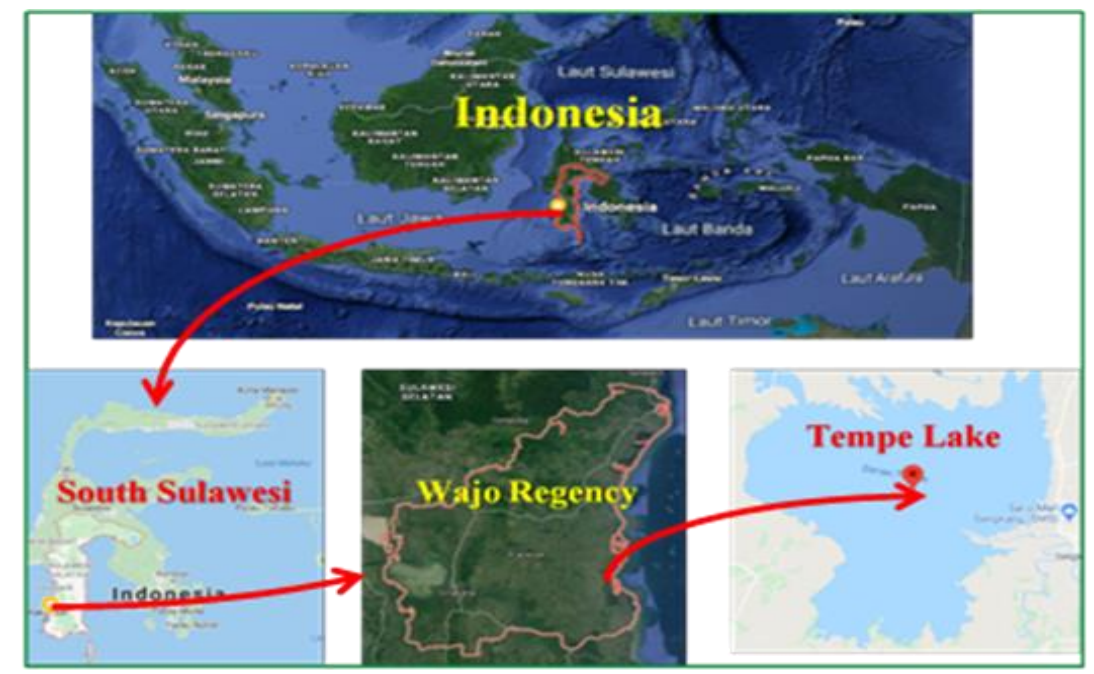

Figure 1. Location of exploration activities in Lake Tempe

\subsection{Research instrument}

Interview guidelines and questionnaires were used as the instruments for data collection in this study [55]. The questionnaire was developed and modified from Surakusumah, Koesbandiah, and Nilawati [56] to examine Lake Tempe's feasibility as a learning resource for the environmental biology course. The indicators of the questionnaire consisted of: 1) Ease of access; 2) Security; 3) Time and cost efficiency; 4) Relevance to the teaching materials as shown in Table 1. The questionnaire used the Guttman scale, consisting of statements in the form of a checklist with a yes or no choice.

The instrument used to measure the students' cognitive learning outcomes were 25 multiple-choice questions. The questions were developed based on the learner's performance on water pollution and alternative problem-solving. The questions were formulated according to the cognitive levels set by Bloom's taxonomy version.

Table 1. Lake Tempe feasibility tool grid as a learning resource

\begin{tabular}{lcl}
\hline \multicolumn{1}{c}{ Indicator } & No & \multicolumn{1}{c}{ Statement } \\
\hline Ease of access & 1 & Lake Tempe is close to the campus location. \\
& 2 & The location of Lake Tempe is close to the residence of the pre-service biology teachers. \\
3 & The location of Lake Tempe is accessible by land and water transportation. \\
& 4 & Lake Tempe is easy to find on the google map. \\
& 5 & The road access to Lake Tempe is good, so it is not dangerous to visit the area. \\
Security & 1 & The Lake Tempe area is close to the housing complex. \\
Time efficiency & 2 & Some officers or guides can accompany you as you go to Lake Tempe. \\
& 1 & It takes less than 30 minutes to reach Lake Tempe on foot. \\
Cost efficiency & 2 & It takes less than 10 minutes to reach Lake Tempe by motorcycle. \\
Relevance to the teaching materials & 1 & There is no registration/ticket fee for visiting the lake. \\
& 1 & Lake Tempe deals with the interaction of living things with the environment \\
& 2 & Lake Tempe deals with the physicochemical parameters of water. \\
& 3 & Lake Tempe deals with water pollution. \\
& 4 & Lake Tempe deals with the diversity of microorganisms.
\end{tabular}




\subsection{Data collection}

The data were collected based on the objectives of the study. The data consisted of: 1) Physicochemical parameters of Lake Tempe water: water samples were obtained at three points, namely in the inlet area $\left(119^{0} 28^{\prime} 13^{\prime \prime} \mathrm{E}, 4^{0} 02^{\prime} 10^{\prime \prime} \mathrm{S}\right)$, in the middle are $\left(119^{0} 27^{\prime} 29^{\prime \prime} \mathrm{E}, 4^{0} 03^{\prime} 34^{\prime \prime} \mathrm{S}\right)$, and in the outlet area $\left(119^{0} 27^{\prime} 15^{\prime \prime} \mathrm{E}, 4^{0} 03^{\prime} 42^{\prime}\right.$ 'S). Sampling and testing were carried out twice with an interval of one day. It is assumed that their presence represented the physicochemical parameters measured, and the piece of seawater at each point was performed by random selection (taking a moment). Water samples were taken at 9-10 a.m. with a long-handled plastic shovel following SNI 6989.59-2008 concerning the method of wastewater sampling.

The Observed Parameters of Lake Tempe water is shown in Table 2. Furthermore, the water samples were placed in 1-liter plastic polyethylene bottles. Temperature, $\mathrm{pH}$, DO, TSS of the water samples were measured directly on-site, and DO parameters were measured in the laboratory. Table 2 shows the measuring instruments. 2) Human activities that may pollute Lake Tempe, resulting from face-to-face interviews with people living in the coastal areas; 3) Identification of aquatic plants found during the exploration operations. The transect method was applied to collect aquatic plant samples from each research station. Each transect had a size of $2 \times 2$ meters. The plants were taken out of the water slowly to remain intact. The collected aquatic plants were stored in plastic samples and preserved with $40 \%$ alcohol, and identified in the laboratory. The aquatic plant species were collected, observed, and then documented and compared with the Southeast Asian book about aquatic weeds.

The results of the exploration activities were compared with the Environmental Biology learning materials. The students' exploration activities were compared to the students' achievement and cognitive learning outcomes. The relevance to the material was determined based on the field data. The feasibility survey was conducted by distributing a questionnaire to the student participants. After coming back from a field-trip from Lake Tempe, the students were asked to do a test.

\begin{tabular}{cccc}
\multicolumn{4}{c}{ Table 2. Observed parameters of Lake Tempe water } \\
\hline Parameter & Unit & Laboratory equipment & Measurement \\
\hline Temperature & ${ }^{\circ} \mathrm{C}$ & Thermometer digital & In-situ \\
Brightness & $\mathrm{Cm}$ & Disk Secchi & In-situ \\
Depth $(\mathrm{cm})$ & $\mathrm{Cm}$ & Peilschaal & In-situ \\
pH & - & Portable pH meter & In-situ \\
DO & $\mathrm{mg} / \mathrm{L}$ & Do meter digital & In-situ \\
BOD & $\mathrm{mg} / \mathrm{L}$ & Winkler & Ex-situ \\
\hline
\end{tabular}

\subsection{Data analysis}

Data from the exploratory research and observation were described based on the on-field study results. The interview and questionnaire results were analyzed descriptively. The questionnaire's responses were expressed in a percentage calculated using the following formula:

$$
\text { Persentage }=\frac{\sum \text { score }}{n \times \text { highes value } \times r} \times 100 \%
$$

Note:

$\mathrm{n}=$ The sum of questionnaire items

$\mathrm{r}=$ The total number of respondents

The percentage of each indicator was interpreted based on the categories performed by Surakusumah, Koesbandiah, and Nilawati [56]. The interpretation of each type is shown in Table 3. The data on the students' learning outcomes were analyzed qualitatively and descriptively. The pre-test and post-test data were analyzed using the Paired Sample t-test. Before conducting the t-test, the normality of the data was tested using Kolmogorov Smirnov in SPSS. If the probability was $>$ the significance level (alpha=5\%), the data were considered normal [57]. The data normality result is presented in Table 4.

Based on the normality test result, it was reported that the learning outcome data were distributed normally with a probability of 0.134 , which is $>$ alpha $(5 \%)$. Therefore, it was concluded that the data had a normal distribution. 
Table 3. Lake Tempe feasibility category

\begin{tabular}{cc}
\hline Percentage & Interpretation \\
\hline $81 \% \leq$ score of $\leq 100 \%$ & Very decent \\
$61 \% \leq$ score of $\leq 80 \%$ & Decent \\
$41 \% \leq$ score of $\leq 60 \%$ & Fairly decent \\
$21 \% \leq$ score of $\leq 40 \%$ & Insufficient \\
$0 \% \leq$ score of $\leq 20 \%$ & Not feasible \\
\hline
\end{tabular}

Table 4. Normality test of the students' learning outcomes

\begin{tabular}{ccccc}
\hline Residual for dependent & Kolmogorov Smirnov & $\mathrm{N}$ & Sig. & Decision \\
\hline Learning outcome & 0.137 & 32 & 0.134 & Normal \\
\hline
\end{tabular}

\section{RESULTS AND DISCUSSION}

The documentation of the exploration activities carried out by the pre-service biology teachers is shown in Figure 2 The exploration results are described in terms of historical facts about: 1) The impact of examining the physicochemical water parameters; 2) The development of analyzing community activities that can reduce the quality of Lake Tempe's water; and 3) The effects of identifying aquatic plant species.

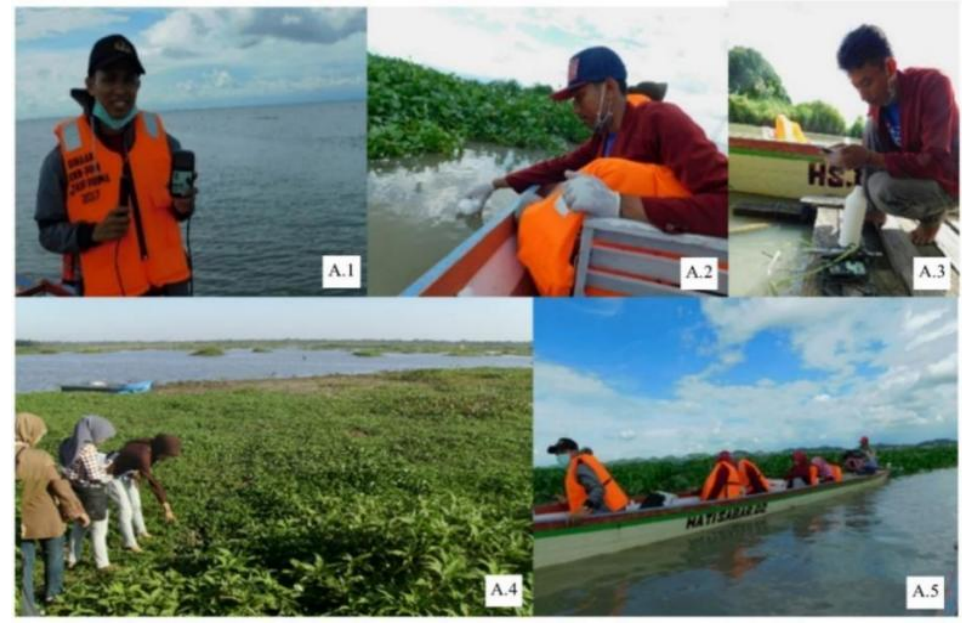

Figure 2. The pre-service biology teachers conducted exploration activities at Lake Tempe; A.1-A.3 measuring the physicochemical parameters of Lake Tempe; A.4-A.5 identification of aquatic plants

\subsection{Physicochemical parameters of Lake Tempe water}

Physicochemical parameters of Lake Tempe water can be used to describe the quality of Lake Tempe. The results of the physicochemical analysis at the three research sites are shown in Table 5. The temperature of Lake Tempe waters ranged between 29.00 and $31.50^{\circ} \mathrm{C}$. The water's lowest temperature was found in the inlet area of the lake, while the highest temperature of the water was found in the middle area of the lake. The water temperature range is always reasonable, which means it has complied with the quality standard set by the Government Decree No. 82 of $2001\left(29\right.$ and $\left.32^{\circ} \mathrm{C}\right)$. This proves that the temperature in Lake Tempe can be categorized as standard for the organisms. In line with the study of Yani, et al. [58], water temperature fluctuates due to the zone's climate situation.

Table 5. The physicochemical analysis of Lake Tempe waters

\begin{tabular}{ccccc}
\hline \multirow{2}{*}{ Parameter } & \multirow{2}{*}{ Quality standard (usual) } & Inlet & $\begin{array}{c}\text { Station } \\
\text { Middle }\end{array}$ & Outlet \\
\hline Temperature $\left({ }^{\circ} \mathrm{C}\right)$ & $28-32$ & 29.00 & 31.50 & 30.00 \\
Brightness $(\mathrm{cm})$ & - & 18.71 & 29.31 & 27.76 \\
Depth $(\mathrm{cm})$ & - & 142 & 174 & 155 \\
$\mathrm{DO}(\mathrm{mg} / \mathrm{L})$ & $>4$ & 5.40 & 4.60 & 3.95 \\
$\mathrm{pH}(\mathrm{mg} / \mathrm{L})$ & $6-9$ & 6.5 & 6.00 & 7.50 \\
$\mathrm{BOD}(\mathrm{mg} / \mathrm{L})$ & 3 & 6.50 & 5.50 & 6.50 \\
\hline
\end{tabular}


The water brightness of the middle area of the lake was between 18.71 and $29.31 \mathrm{~cm}$. Normal light supports the life of aquatic organisms. The central area of the lake may have high water brightness because it is the least polluted area. There is no overhaul or decomposition by aquatic organisms. The water is clear, and the light transmission is higher compared to the inlet and outlet areas. The lowest brightness $(18.71 \mathrm{~cm})$ was found in the inlet area because it is close to a region's residential area. The municipality uses the lake for daily activities such as bathing, washing, disposing of household waste or municipal waste. A low brightness of water can affect the organisms living in the water [55], [58]. According to Li and Liu [59], lower intensity of illumination results in worse quality of water.

The $\mathrm{pH}$ measured at each research station was between 6.5 and 7.5, which is in the lowest permissible range. This may be caused by human agricultural activities that are conducted around the lake [58]. The high concentration of natural substances penetrating water may lower the water's $\mathrm{pH}$, where the water becomes more acidic instead of raw [60].

The dissolved oxygen (DO) in the water varied between 3.95 and $5.40 \mathrm{mg} / \mathrm{l}$. A high concentration of dissolved oxygen in the lake's outlet area can be associated with the water's low temperature. This statement is in line with the opinion [61] that weather significantly influences oxygen solubility. When the climate is intense, the oxygen in the water increases. According to $\mathrm{Li}$ and Liu [62], oxygen dissolved in water is generated from the photosynthesis process of aquatic plants and the air through the diffusion process that slowly penetrates the water surface. Dissolved oxygen is also heavily influenced by many factors such as temperature, salinity, and photosynthesis. Despite so, the DO content in the Lake Tempe outlet area is considered good.

The BOD value is a value that indicates the oxygen content needed by aerobic bacteria to oxidize organic matter in water. Indirectly, BOD also suggests the presence of organic matter in water. The highest BOD value in Lake Tempe was found at the inlet (6.50), middle (5.50), and outlet (6.50) areas, with an average range of 5.50-6.50 $\mathrm{mg} / \mathrm{L}$. Judging from this value, the water's BOD values have exceeded the minimum limit of $3 \mathrm{mg} / \mathrm{L}$ (Government Regulation of the Republic of Indonesia No. 82, 2001). The high BOD value in the inlet section can be associated with the low DO value in the inlet section, and it is believed that the inlet contains much organic waste. The amount of oxygen that microbes need to decompose organic materials is significant, which means that the BOD number is high; with much oxygen required to break down the organic materials, the dissolved oxygen content (5.40) inlet will decrease. According to the opinion of Penn, Pauer, and Mihelcic [63], the DO value will decrease when the BOD value increases. Overall, it can be seen that the Lake Tempe outlet area is in excellent condition compared to other stations.

\subsection{Community activities in the coastal region of Lake Tempe that pollute the lake}

Based on the results of field exploration, the differences in the effects of the three stations' physicochemical parameters became apparent. The difference in the lake's physicochemical parameters was influenced by various factors, namely by anthropogenic activities. The community activities that resulted in Lake Tempe pollution are presented in Table 6. The activities include washing, bathing, farming, manure disposal, throwing plastic or glass waste into the lake, and dumping manure into the lake through pipes.

Table 6 shows that human activities have resulted in polluting Lake Tempe. The activities that contributed most to the pollution were washing, bathing, recreation, and excrement dropping directly from the residents' houses because the people had no septic tanks. According to previous research [55], washing and bathing offer a significant opportunity for detergent pollution, increasing the water $\mathrm{pH}$ and temperature.

Table 6. Human activities that lead to pollution

\begin{tabular}{clcccc}
\hline \multirow{2}{*}{ No } & \multirow{2}{*}{ Indicators } & \multicolumn{2}{c}{ Frequency } & \multicolumn{3}{c}{ Percentage $(100 \%)$} \\
& & Yes & No & Yes & No \\
\hline 1 & Used for bathing & 130 & 20 & 86.67 & 13.33 \\
2 & Used for washing clothes & 145 & 5 & 96.67 & 3.33 \\
3 & Dispose of bottles, cans, glass in the lake & 82 & 68 & 55.67 & 45.33 \\
4 & Throw feces to the lake & 58 & 92 & 38.67 & 61.33 \\
5 & Tillage around the lake & 127 & 23 & 84.67 & 15.33 \\
6 & Place for recreation & 72 & 78 & 48.00 & 52.00 \\
7 & Have the septic tanks & 110 & 40 & 73.33 & 26.67 \\
8 & Dispose of used oil & 30 & 120 & 20.00 & 80.00 \\
\hline
\end{tabular}

\subsection{Aquatic plants identified in Lake Tempe}

Another potential of Lake Tempe is that it provides information about aquatic plants relevant for contextual learning. Based on the field investigation results, nine aquatic plant species belonging to six families were identified in Lake Tempe as shown in Table 7. The number of aquatic plant species found in 
Lake Tempe was determined based on their substrate type and current type. The lake's surface is muddy with some sand, and there are small stones found in the lake. The aquatic plants also serve as a living habitat for seed plants. The shoots of underwater plants adhere to these sub-extracts and are scattered in between. The predominant life patterns are emergent, floating (leaves), and submerged shown in Table 7. The currents are medium and sometimes calm. According to previous research [64], water currents significantly impact aquatic plants' growth, and steady currents increase the frequency and variety of aquatic plants, while solid winds inhibit growth.

Community activities in the coastal area of Lake Tempe impact the abundance of aquatic plants [65], [66]. According to previous research [36], waste from agricultural land and households containing organic materials fertilizes lake water. The effects are based on observations made on the field and one of the flowering plant species. One of the aquatic plant species, Eichhornia crassipes, is an indicator/marker that Lake Tempe is currently showing a decrease in water quality [64], [67]. Eichhornia crassipes can accumulate (reduce) the concentration of organic pollutants using phytoremediation techniques. Similarly, Kumar [68] reported that aquatic plants can be used as eco-technology (environmental technology) to prevent contamination of household and agricultural waste.

Based on the explorations carried out by the pre-service biology teachers, it was known that Lake Tempe could be used as a resource of contextual learning. The findings obtained by the students have been empirically proven. The facts obtained from the exploration activities included factual knowledge, conceptual knowledge, and procedural knowledge. Therefore, Lake Tempe's feasibility as a learning resource should be adjusted to analyze the environmental biology curriculum.

\begin{tabular}{cll} 
Table 7. Aquatic plants identified in Lake Tempe \\
\cline { 2 - 3 } No & \multicolumn{1}{c}{ Species } & Way of life \\
\hline 1 & Scirpus grossus & Emergent \\
2 & Limnocharis flava & Emergent \\
3 & Hydrilla verticillata. & Submerged \\
4 & Polygonum barbatum & Floating Leave \\
5 & Ottelia alismoides & Floating Leave \\
6 & Nymphaea lotus & Floating Leave \\
7 & Echinochloa colonum & Emergent \\
8 & Eichhornia crassipes & Free Floating \\
9 & Cyperus platystylis & Emergent \\
\hline
\end{tabular}

\subsection{Analysis of the feasibility of Lake Tempe as a learning resource}

Lake Tempe's feasibility as a learning resource can be examined through students' learning outcomes, responses, and direct observations.

\subsubsection{The relevance of Lake Tempe's potential as a learning resource}

Lake Tempe exploration and observation results can develop learning materials for Environmental Biology (EB) course. The findings on the lake's potential can provide actual knowledge for the pre-service biology teachers. The essential facts collected on the field are shown in Table 8.

Based on Table 8, there is a relevance between the field exploration results in Lake Tempe and environmental biology's learning outcomes. These facts can be used as a source of contextual learning for pre-service biology teachers. Lake Tempe's potential is essential to teach the teachers about integrated local environmental problems. Research by Sulaeman, et al. [38] states that using ecological issues as learning sources is part of the transformation in science education based on the science-environment-technologysociety approach that can improve students' understanding of the environment. As mentioned by Bustami, Syafruddin, and Afriani [28], the development of learning media such as student worksheets should address local potentials and issues, and the development of textbooks should be based on local wisdom [69]. Similarly, Ridhwan, et al. [43] reported that the development of teaching materials could be derived from local potentials. Besides, the survey results also showed that Lake Tempe could be used as a learning resource. 
Table 8. Facts about Lake Tempe's potential as a learning resource

\begin{tabular}{|c|c|c|c|}
\hline No & Learning Outcomes of EB & $\begin{array}{l}\text { Sub of Learning Outcomes of } \\
\text { EB }\end{array}$ & $\begin{array}{c}\text { Facts about Lake Tempe's potential as } \\
\text { a learning resource }\end{array}$ \\
\hline 1 & $\begin{array}{l}\text { Solve various environmental problems through } \\
\text { multiple efforts, including group research. The } \\
\text { research findings should be communicated } \\
\text { pleasantly through class presentations or seminars. }\end{array}$ & $\begin{array}{l}\text { 1.1. Measure water quality by } \\
\text { testing the physical parameters } \\
\text { of water chemistry and } \\
\text { analyzing the results. } \\
\text { 1.2. Identification and evaluation } \\
\text { of aquatic plants as pollutant } \\
\text { bioindicators } \\
1.3 \text { Analysis and assessment of } \\
\text { human activities concerning } \\
\text { changes around the lake's } \\
\text { environment }\end{array}$ & $\begin{array}{l}\text { The physicochemical parameters of } \\
\text { Lake Tempe are determined based on } \\
\text { the physicochemical test. } \\
\text { Identification of aquatic plants in } \\
\text { Lake Tempe } \\
\text { Description of pollutant bioindicators } \\
\text { Anthropogenic activities that affect } \\
\text { the deterioration of water quality in } \\
\text { Lake Tempe }\end{array}$ \\
\hline
\end{tabular}

\subsubsection{The pre-service biology teachers' responses towards Lake Tempe's potential as a learning resource}

Data on the pre-service teachers' responses towards Lake Tempe's potential as a learning resource are presented in Table 9. Based on the Table 9, it was known that $88 \%$ of the pre-service biology teachers agreed to Lake Tempe's potential as a learning resource, and it was relevant to the EB teaching materials. However, the security and cost efficiency were in a decent category with a similar percentage of $55 \%$. The ease of access indicator was considered to be feasible, with a score of $82 \%$. Time efficiency was deemed to be decent with $70 \%$ responses. Based on these findings, it can be concluded that Lake Tempe's potential as a learning resource was decent, with an average score of $70 \%$.

Table 9. Pre-service biology teachers' responses towards Lake Tempe's potential as a learning resource

\begin{tabular}{clcc}
\hline No. & \multicolumn{1}{c}{ Aspect } & Percentage & Feasibility category \\
\hline 1 & Ease of access & $82 \%$ & Decent \\
2 & Security & $55 \%$ & Fairly decent \\
3 & Time efficiency & $70 \%$ & Decent \\
4 & Cost efficiency & $55 \%$ & Fairly decent \\
5 & Relevance with EB course teaching materials & $88 \%$ & Very decent \\
& Average score & $70 \%$ & Decent \\
\hline
\end{tabular}

Lake Tempe can provide a resource for learning. However, the lake's potential should be aligned with the learning outcomes that students should achieve at all education levels. According to previous research [43], the utilization of local potential can enhance learners' comprehension of facts and process skills through direct observations. According to previous research [70], direct observation activities can provide students with experiences and understand phenomena based on facts. However, these activities have weaknesses in cost efficiency and security because they had to rent a boat to Lake Tempe. Thus, their safety was also compromised. Some students were even phobic about water, and therefore they could not travel on boat. However, these students could do the observation from the lake's edge, without having to go to the middle area of the lake.

The local community currently holds Lake Tempe's management, so the visitors do not need to pay for an entry ticket. Because of that, the students and the teacher could obtain cost efficiency from the activity. The lake can provide learners with knowledge about the relationship between living things and the world, water pollution, factors contributing to the breakdown, and aquatic plant species. It can also provide a sense of contextual learning because it is close to the students' daily life situations. As a result, the students felt encouraged to describe the environmental and biological phenomena in Lake Tempe.

Lake Tempe contains objects that can be studied and learned, and it also can serve as a natural laboratory. The use of a natural environment in the EB course can promote self-confidence in ecological protection. Excursions offer learners the opportunity to develop knowledge and skills to add value to teaching experiences [71]. Students are aware of the structure of knowledge so that information can be linked to prior experience. Learning makes sense when students can integrate new phenomena into knowledge structures. The paired sample statistics showed an increase in the students' learning outcome after they were allowed to explore Lake Tempe's potential through direct observation as shown in Table 10.

Table 10 shows that the students' mean score increased by 5.05 after they conducted exploration activities in Lake Tempe. Even though the increase was not too significant, the observation result showed that the students were more actively engaged in classroom discussions and explaining phenomena occurring in Lake Tempe. The paired sample t-test also improved the students' learning outcome as shown in Table 11. 
Table 10. Descriptive analysis of the students' learning outcome

\begin{tabular}{llcccc}
\hline \multicolumn{5}{c}{ Paired samples statistics } \\
& & Mean & N & Std. Deviation & Std. Error mean \\
\hline Pair 1 & LO Pre-test & 80.2881 & 32 & 7.61494 & 1.34614 \\
& LO Post-test & 85.3372 & 32 & 6.72824 & 1.18940 \\
\hline
\end{tabular}

LO: Learning outcome

Table 11. T-test results for the pre-test and post-test

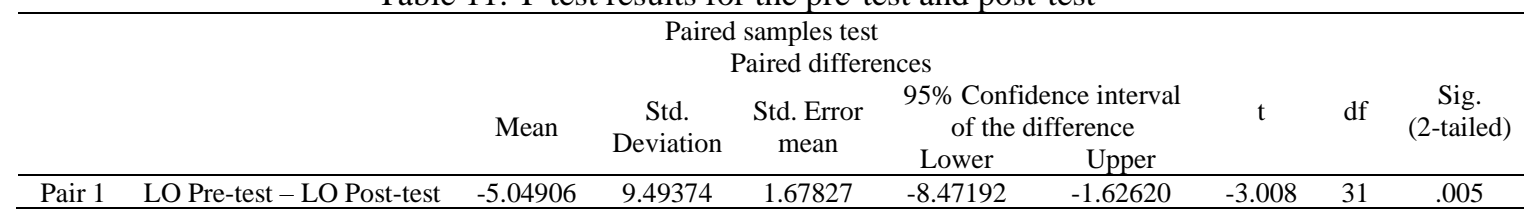

LO: Learning outcome

The data in Table 10 and Table 11 show that there are significant differences in learning outcomes before $(\mathrm{M}=80.2881, \mathrm{SD}=7.6149)$ and after the students conducted exploration activities in Lake Tempe $(\mathrm{M}=85.3372, \mathrm{SD}=6.72824), \mathrm{t}(31)=3.008, \mathrm{p}<0.005$. It can be inferred that there is a discrepancy between the pre-test and post-test mean scores. It indicates that the exploration activities were effective in improving the pre-service biology teachers' learning outcomes. This finding is in line with what was stated by Özkan, Turan, and Topsakal [72] that learning carried out outside the classroom (out of school) was able to improve student achievement at the 6th-grade level. Other researchers stated that learning outside the classroom can improve student achievement, develop scientific process skills, and positively influence student attitudes and motivation [73]. Furthermore, it was reported by Tuuling, Oun, and Ugaste [74] that outdoor learning helps increase children's physical activity.

Student exploration activities at Lake Tempe were able to improve students' ability to connect prior knowledge with the facts they found on site. The students found it easier to understand the problems presented, study facts, plan problem-solving, discuss work results in groups, and complete work results after the exploration activities. It was shown by the students' active involvement in exploring the potential and problems in Lake Tempe. They were enabled to understand, describe, and analyze the learning material when the lake's prospects and problems were used as learning resources. Furthermore, the facts obtained by the students on the field were constructed into contextual knowledge. In line with Tuuling, Oun, and Ugaste [74] that contextual learning allows students to see learning objects and phenomena with all senses. The contextualization of local problems is a critical approach to help students enjoy teaching and learning science [40].

Teaching science will be more effective, meaningful, engaging, contemporary, motivating, and especially fun if done with hands-on experiences and a simple conceptual model [75]. Besides, science learning that is integrated with local potential provides a different experience for students, makes learning more meaningful, and improves students' understanding of concepts [26]. Furthermore, other researchers stated that local, regional problems as a learning source effectively improve science process skills [56] and environmental literacy [28]. Learning activities outside the classroom make it possible for students to observe objects and phenomena so that contextual learning improves their conceptual mastery and improves their process skills, problem-solving, and scientific attitudes [76]. Furthermore, other researchers argue that contextual learning by utilizing the environment outside the classroom effectively enhances students' cognitive ability [72], pro-environmental attitudes (EA), and environmental behavior (EB) [77].

Learning by utilizing the local potential/issue of Lake Tempe as a form of contextual learning can improve the pre-service biology teachers' learning outcome. Past studies found that using the surrounding environment, such as museums, as a learning resource helps mediate active learning [78] to increase student knowledge [72]. Besides, the feasibility of local potential as a learning resource in this study is also relevant to the environmental biology course's learning outcome. This fact will strengthen the urgency of contextual learning by utilizing local issues as a learning resource. Therefore, tertiary institutions should accommodate contextual understanding by encouraging students to study local problems.

However, this study also found that some pre-service biology teachers still had poor learning outcomes and had negative responses towards Lake Tempe's potential as a learning resource. Thus, in addition to applying contextual learning, using the knowledge to improve students' learning outcomes and other skills is highly recommended. Research shows that to maximize hands-on activities in science learning. It is necessary to integrate information and communication technologies (ICT) in the classroom [79], where ICT functions as a complement to the learning process [80]. By integrating exploration activities with ICT, 
students will have one of the skills of the 21st century [80], [81]. In addition to combining contextual learning with ICT and other learning strategies, it is also necessary to apply an assessment process that supports exploration activities, student cognitive learning outcomes, and other required skills.

This study recommends Lake Tempe as a potential resource for contextual learning. The learning resources found in Lake Tempe are also relevant to the outcomes of the environmental biology course. Besides, Lake Tempe's effectiveness and feasibility as a learning resource have been confirmed by the participants' cognitive learning outcomes and responses towards the exploration activities conducted at the lake. Studies on the development of learning media based on local potentials and local issues should be undertaken to make the exploration activities more focused and straightforward. The learning media can be in the form of teaching materials, textbooks, worksheets, and modules. Further research is expected to look at other aspects such as students' conceptual changes, creativity, and critical thinking in environmental biology courses by utilizing local potentials or local issues.

\section{CONCLUSION}

Lake Tempe has several potentials that can be used as a learning resource, especially for pre-service biology teachers. These potentials include the water's physicochemical parameters, community activities that cause pollution, and aquatic plant species. The observation data showed that some of the lake's physiochemical parameters had exceeded the lake water's standardized tolerant limits, suggesting that the lake has been polluted. This finding is reinforced by the reaction of the people living in the coastal region of Lake Tempe. They admitted that they used the lake for their daily activities. Uncontrolled anthropogenic activities by the community result in Lake Tempe becoming contaminated with pollutants. Another potential that Lake Tempe can provide as a learning resource is the diversity of plant species. The potential and local problems of Lake Tempe are relevant to the material taught in the environmental biology course. Lake Tempe's feasibility as a learning resource was examined from the following criteria: ease of access, safety, time efficiency, cost efficiency, and relevance to the EB learning materials. The pre-test and post-test data showed that the students' cognitive learning outcomes improved after exploring Lake Tempe's exploration activities. Additionally, the data analyzed showed a difference in the pre-test and post-test mean scores, indicating that the exploration activities conducted around Lake Tempe effectively improved the pre-service biology teachers' cognitive learning outcome. Therefore, Lake Tempe's local potentials and local problems can be used as a contextual learning resource for pre-service biology teachers.

\section{ACKNOWLEDGEMENTS}

The authors would like to thank the institutions that helped to realize this research. This research supported by the Indonesia Endowment Fund for Education PRJ-6586/LPDP.3/2016 and the Ministry of Research, Technology, and Higher Education of the Republic of Indonesia as the scholarship provider from the Ministry of Finance Indonesia.

\section{REFERENCES}

[1] R. Pinheiro and M. Young, "The university as an adaptive resilient organization: a complex systems perspective," in Theory and Method in Higher Education Research. Emerald Publishing Limited, 2017, pp. 119-136.

[2] V. V. Grinshkun, "Definition of Approaches to Complex Research of Information Educational Environment in General, Professional and Additional Education Systems," Rudn J. Informatiz. Educ., vol. 16, no. 1, pp. 12-21, Dec. 2019.

[3] D. Maulina, M. A. Priadi, D. Lengkana, T. Jalmo, A. S. Fauzisar, and M. Amin, "Book of Insects' Immune System: Development and Implementation With PBL in Increasing Students' Learning Outcome," Biosfer, vol. 13, no. 1, pp. 42-58, 2020

[4] L. Caporarello, B. Manzoni, and B. Panariello, "The Evolution of (Digital) Learning Models and Methods: What Will Organizations and Their Employees Adopt in 2025?" in Digital Transformation and Human Behavior. Lecture Notes in Information Systems and Organisation, vol. 37. Springer, Cham, 2021, pp. 11-19.

[5] D. Astriani, H. Susilo, H. Suwono, B. Lukiati, and A. Purnomo, "Mind Mapping in Learning Models: A Tool to Improve Student Metacognitive Skills,” Int. J. Emerg. Technol. Learn., vol. 15, no. 6, pp. 4-17, 2020.

[6] J. L. Branchaw, P. A. Pape-Lindstrom, K. D. Tanner, S. A. Bissonnette, T. L. Cary, B. A. Couch, et al., "Resources for Teaching and Assessing the Vision and Change Biology Core Concepts," CBE-Life Sci. Educ., vol. 19, no. 2, p. es1, 2020.

[7] J. M. D. Roberts, "How Might Covid-19 Affect the Biology Curricula of the Future? Two Principles for Curriculum Developers to Consider," Prospects, pp. 1-5, Jan. 2021, doi: 10.1007/s11125-020-09531-9.

[8] M. S. Shamim, A. Torda, L. A. Baig, N. Zubairi, and C. Balasooriya, "Systematic Development and Refinement of A Contextually Relevant Strategy for Undergraduate Medical Ethics Education: A Qualitative Study," BMC Med. Educ., vol. 21, no. 1, p. 9, Dec. 2021. 
[9] S. McBride, L. Thomas, and S. Decker, "Competency Assessment in Simulation of Electronic Health Records Tool Development," CIN Comput. Informatics, Nurs., vol. 38, no. 5, pp. 232-239, May 2020.

[10] H. Chandir, "Student Responses on The Survey of Global Competence in PISA 2018," Discourse Stud. Cult. Polit. Educ., 2020, doi: 10.1080/01596306.2020.1844153.

[11] E. O. Crawford, H. J. Higgins, and J. Hilburn, "Using A Global Competence Model in An Instructional Design Course Before Social Studies Methods: A Developmental Approach to Global Teacher Education,” J. Soc. Stud. Res., vol. 44, no. 4, pp. 367-381, Oct. 2020.

[12] S. Nerita, A. Maizeli, and A. Afza, "Validity of Assessment Attitude and Values System Based on Indonesian National Qualification Framework on Process Evaluation and Biological Learning Outcomes," J. Penelit. Pendidik. IPA, vol. 6, no. 2, pp. 190-193, Jun. 2020.

[13] T. K. Belmawa, "Learning Outcomes of the Study Program Graduates," in Guidelines for the Preparation of Learning Outcomes for Study Program Graduates, (in Bahasa). Jakarta: Dirjen Belmawa Kemenristekdikti, 2014.

[14] C. R. Prihantoro, "The Perspective of Curriculum in Indonesia on Environmental Education," Int. J. Res. Stud. Educ., vol. 4, no. 1, pp. 77-83, 2014

[15] T. Suminar, T. Prihatin, and M. I. Syarif, "Model of Learning Development on Program Life Skills Education for Rural Communities," Int. J. Inf. Educ. Technol., vol. 6, no. 6, pp. 496-499, 2016.

[16] I. Martiningsih, Lisdiana, and S. M. E. Susilowati, "Development of Module Based on Scientific Contextual Additives Material to Increase Learning Outcomes and Science Process Skills in Junior High School," J. Innov. Sci. Educ., vol. 8, no. 2, pp. 128-137, 2019.

[17] K. Széll, "Factors determining student achievement," Hungarian Educ. Research J., vol. 3, no. 3, pp. 55-66, 2013.

[18] W. Te Winkel, R. Rikers, S. Loyens, and H. Schmidt, "Influence of learning resources on study time and achievement scores in a problem-based curriculum," Adv. Heal. Sci. Educ., vol. 11, no. 4, pp. 381-389, Nov. 2006.

[19] S. Saraswati, R. Linda, and H. Herdini, "Development of Interactive E-Module Chemistry Magazine Based on Kvisoft Flipbook Maker for Thermochemistry Materials at Second Grade Senior High School," J. Sci. Learn., vol. 3, no. 1, pp. 1-6, 2019.

[20] A. Yani, Sahriah, and R. Adiansyah, "Developing Problem-Based Learning Module For Biotechnology Concepts," J. Pendidik. Sains, vol. 5, no. 2, pp. 46-56, 2017.

[21] D. Suryanti, P. Sinaga, and W. Surakusumah, "Improvement of Students' Environmental Literacy by Using Integrated Science Teaching Materials," IOP Conf. Ser.: Mater. Sci. Eng., vol. 306, 2018.

[22] B. L. Ong'amo, S. R. Ondigi, and A. Omariba, "Effect of Utilization of Biology Teaching and Learning Resources on Students' Academic Performance in Secondary Schools in Siaya District - Kenya," Master Thesis, Kenyatta University, 2017.

[23] A. S. Widodo, "Selection of Learning Media Mathematics for Junior School Students," TOJET Turkish Online J. Educ. Technol., vol. 17, no. 1, pp. 154-160, Jan. 2018.

[24] S. Kuppusamy and T. Mari, "Relationship Between Environmental Awareness and Environmental Knowledge Using 'AKASA' Model Among Architecture Students in Private Universities, Klang Valley, Malaysia," in 2017 2nd International Conference on Knowledge Engineering and Applications (ICKEA), 2017, pp. 151-155.

[25] M. J. Susilo, "Analysis of Environmental Potential as a Useful Source of Biological Learning," Procending Biol. Educ. Conf., vol. 15, no. 1, pp. 541-546, 2018.

[26] I. P. M. Dewi, I. G. P. Suryadarma, I. Wilujeng, and S. Wahyuningsih, "The effect of science learning integrated with local potential of wood carving and pottery towards the junior high school students' critical thinking skills," J. Pendidik. IPA Indones., vol. 6, no. 1, 2017.

[27] L. G. Quive, S. Leandro, E. C. Bandali, G. A. Gueze, D. A. João, A. M. Gomundanhe, N. F. Neuana, et al., "Exploring Materials Locally Available to Teach Chemistry Experimentally in Developing Countries," Educ. Chem. Eng., vol. 34, pp. 1-8, Jan. 2021.

[28] Y. Bustami, D. Syafruddin, and R. Afriani, "The implementation of local environmental problem-based learning student worksheets to strengthen environmental literacy," J. Pendidik. IPA Indones., vol. 9, no. 2, pp. 169-178, Jun. 2020.

[29] E. Suryawati, K. Osman, and T. S. M. Meerah, "The effectiveness of RANGKA Contextual Teaching and Learning on Student's Problem Solving Skills and Scientific Attitude," in Procedia - Social and Behavioral Sciences, vol. 9, pp. 1717-1721, Jan. 2010.

[30] D. Maulina and M. Amin, "The analysis of necessity teaching materials on animal physiology learning in Lampung University," in Prosiding Seminar Nasional II, Universitas Muhammadiyah Malang, 2016, pp. 1072-1076.

[31] E. van Laar, A. J. A. M. van Deursen, J. A. G. M. van Dijk, and J. de Haan, "The relation between 21st-century skills and digital skills: A systematic literature review," Comput. Human Behav., vol. 72, pp. 577-588, Jul. 2017.

[32] Juniwati, Yusrizal, and I. Khaldun, "Influence of The Contextual Teaching and Learning Model Against Student Learning Outcome," in Journal of Physics: Conference Series, vol. 1460, no. 1, Mar. 2020.

[33] J. Bidarra, C. Natalio, and M. Figueiredo, "Contextual Learning," in International Conference on Interactive Mobile Communication Technologies and Learning (IMCL), 2014, pp. 5-13.

[34] E. Suryawati and K. Osman, "Contextual learning: Innovative approach towards the development of students' scientific attitude and natural science performance," Eurasia J. Math. Sci. Technol. Educ., vol. 14, no. 1, pp. 61-76, Oct. 2018.

[35] A. Yani, M. Amin, F. Rohman, E. Suarsini, and Haerunnisa, "Water Quality and Pollution Index of Lake Tempe in Sounth Sulawesi Indonesia,” Pollut. Res., vol. 38, no. 3, pp. 54-60, 2019. 
[36] H. Haerunnisa, B. Budimawan, S. Alam Ali, and A. I. Burhanuddin, "Management Model of Sustainability Fisheries at Lake Tempe, South Sulawesi, Indonesian," Int. J. Sci. Res., vol. 4, no. 5, pp. 2319-7064, 2015.

[37] E. Bozoti and R. L. Bozelli, "An analysis of curriculum and undergraduate students' discourses about environmental education: A debate concerning teacher training," Int. J. Environ. Sci. Educ., vol. 11, no. 18, pp. 12197-12234, 2016.

[38] N. F. Sulaeman, A. Nuryadin, R. Widyastuti, and L. Subagiyo, "Air Quality Index and The Urgency of Environmental Education in Kalimantan," J. Pendidik. IPA Indones., vol. 9, no. 3, pp. 371-383, 2020.

[39] T. L. Fleischner, et al., "Teaching Biology in the Field: Importance, Challenges, and Solutions," Bioscience, vol. 67, no. 6, pp. 558-567, Jun. 2017.

[40] F. P. Tupas, "Nature feature: The use of local biodiversity in science pedagogy," African Educ. Res. J., vol. 7, no. 3, pp. 153-162, 2019.

[41] A. Yani, M. Amin, F. Rohman, and E. Suarsini, "Profile of teaching materials environment biology and ability preservice biology teacher to communicate laboratory report," Int. J. Humanit. Soc. Sci. Educ., vol. 6, no. 3, pp. 1-5, 2019.

[42] A. Ilhami, Riandi, and S. U. Sovia, "A Profile of Biology and Science Teacher'S Knowledge About Local Wisdom Ikan Larangan in West Sumatera," PUPIL Int. J. Teaching, Educ. Learn., vol. 3, no. 1, pp. 173-180, 2019.

[43] Ridhwan, Sumarmi, I. N. Ruja, D. H. Utomo, and R. M. Sari, "Student perception on teaching materials development to increase students' knowledge of Aceh's Maritime potential," J. Educ. Gift. Young Sci., vol. 7, no. 4, pp. 1295-1309, 2019.

[44] E. Fatmawati, "Monographs as a way of publishing books from research results," (in Bahasa), IQRA J. Ilmu Perpust. dan Inf., vol. 14, no. 1, pp. 130-155, 2020, doi: 10.30829/iqra.v14i1.7721.

[45] R. Fadli, M. Amin, and U. Lestari, "Monograph Development of Genetic Matter Expression with Thiagarajan Model Based on Research on Twinning Rate Gene in Twin Cows," (in Bahasa), J. Pendidik. Teor. Penenlitian, dan Pengemb., vol. 2, no. 11, pp. 1539-1542, 2017.

[46] R. Islam, H. Yu, R. Abbassi, V. Garaniya, and F. Khan, "Development of a Monograph for Human Error Likelihood Assessment in Marine Operations," Saf. Sci., vol. 91, pp. 33-39, 2017.

[47] S. Ramdiah, A. Abidinsyah, M. Royani, H. Husamah, and A. Fauzi, "South Kalimantan Local Wisdom-Based Biology Learning Model," Eur. J. Educ. Res., vol. 9, no. 2, pp. 639-653, 2020.

[48] J. Paulo and C. Cruz, "Development of an Experimental Science Module to Improve Middle School Students' Integrated Science Process Skills," DLSU Res. Congr. 2015, vol. 3, pp. 1-6, 2015.

[49] R. Linda, H. Herdini, I. S. S, and T. P. Putra, "Interactive E-Module Development through Chemistry Magazine on Kvisoft Flipbook Maker Application for Chemistry Learning in Second Semester at Second Grade Senior High School," J. Sci. Learn., vol. 2, no. 1, p. 21, 2018.

[50] F. Habaora, A. M. Fuah, L. Abdullah, R. Priyanto, A. Yani, and B. P. Purwanto, "Economic Analysis of Bali Cattle Farm in Timor Island Indonesia," Int. J. Sci. Technol. Res., vol. 8, no. 10, 2019.

[51] Z. Ariefiani, D. Kustono, and S. Pathmantara, "Module development with project-based learning approach and assure development model," AIP Conf. Proc., vol. 1778, no. 2016, 2016.

[52] S. Techakosit and P. Wannapiroon, "Connectivism Learning Environment in Augmented Reality Science Laboratory to Enhance Scientific Literacy,” Procedia - Soc. Behav. Sci., vol. 174, no. 2, pp. 2108-2115, 2015.

[53] C. Weng, S. Otanga, S. M. Christianto, and R. J. C. Chu, "Enhancing Students' Biology Learning by Using Augmented Reality as a Learning Supplement," J. Educ. Comput. Res., vol. 58, no. 4, pp. 747-770, 2020.

[54] M. Figueiredo and J. Bidarra, "The development of a gamebook for education," Procedia Computer Science, vol. 67 , pp. $322-331,2015$.

[55] M. Rijal, M. Amin, F. Rochman, E. Suarsini, and N. Alim, "The quality of physical and chemical the waters of the arbes Ambon," Int. J. Multidisiplinary Res. Dev., vol. 2, no. 4, pp. 87-92, 2015.

[56] W. Surakusumah, H. S. Koesbandiah, and T. S. Nilawati, "Feasibility Study of Cilaja River As Learning Sources for Freshwater Biology CourseTo Improve Science Process Skills," The 3rd Annual International Seminar on Trends in Science and Science Education, 2016, pp. 213-217.

[57] C. A. Mertler and R. A. Vannatta, Advanced and multivariate statistical methods: Practical application and interpretation, 6th edition. Los Angeles: Pyrczak Publishing, 2016.

[58] A. Yani, M. Amin, F. Rohman, E. Suarsini, and Haerunnisa, "Water quality and pollution index of Lake Tempe in South Sulawesi Indonesia," Pollut. Res., vol. 1, no. 3, 2019.

[59] D. Li, and S. Liu, "Water Quality Evaluation," in Water Quality Monitoring and Management. Academic Press, 2019, pp. 113-159.

[60] Z. Wu, X. Wang, Y. Chen, Y. Cai, and J. Deng, "Assessing river water quality using water quality index in Lake Taihu Basin, China," Sci. Total Environ., vol. 612, pp. 914-922, 2018.

[61] D. H. Dumouchelle and E. A. Stelzer, "Chemical and Biological Quality of Water in Grand Lake St. Marys, Ohio, 2011-12, with Emphasis on Cyanobacteria," Scientific Investigations Report. U.S. Geological Survey, 2014, doi: $10.3133 /$ sir20145210.

[62] D. Li and S. Liu, "Water Quality Detection for Lakes," in Water Quality Monitoring and Management. Academic Press, 2019, pp. 221-231

[63] M. R. Penn, J. J. Pauer, and J. R. Mihelcic, "Biochemical Oxygen Demand," Environmental and Ecological Chemistry, vol. II, 2011.

[64] A. Aly, S. Shawkya, M. El-Tahawyaan, and A. T. Kandil, "Investigation of Eichhornia crassipes as a Bio-Indicator and Bio-Accumulator for Radionuclides Along the Rosette Nile Branch- Egypt," Proceedings of the Eighth Conference of Nuclear Sciences and Applications, 2004. 
[65] S. Aisyah and S. Nomosatryo, "Spatial and Temporal Distribution of Nutrient in Lake Tempe, South Sulawesi," Oseanologi dan Limnol., vol. 1, no. 2, pp. 31-45, 2016.

[66] A. Yani, M. Amin, F. Rohman, and E. Suarsini, "The behavior of the coastal area Lake Tempe against the deterioration of the water quality and its control strategy," in Seminar Nasional Biologi Universitas Hasanuddin Makassar, 2018, pp. 156-165.

[67] A. Yani, M. Amin, F. Rohman, E. Suarsini, and W. E. Putra, "Profiling indigenous lead-reducing bacteria from Tempe Lake, South Sulawesi, Indonesia as bioremediation agents," Biodiversitas, vol. 21, no. 10, pp. 4778-4786, 2020, doi: 10.13057/biodiv/d211043.

[68] J. I. Nirmal Kumar, H. Soni, R. N. Kumar, and I. Bhatt, "Macrophytes in phytoremediation of heavy metal contaminated water and sediments in urban inland ponds," Turkish J. Fish. Aquat. Sci., vol. 8, pp. 193-200, 2008.

[69] S. Sujinah, M. A. Mu'ammar, A. N. Affandy, and E. Supriyanto, "The Effectiveness of Local Wisdom based on textbook to improve students' writing literacy," Univers. J. Educ. Res., vol. 7, no. 12, pp. 2573-2583, 2019.

[70] A. E. Bozdoğan, "Determination of Turkish Prospective Teachers' Past Field Trip Experiences and Examination of Their Self-Efficacy Beliefs in Planning and Organising Educational Field Trips Regarding Various Variables," Particip. Educ. Res., vol. 5, no. 2, pp. 1-17, 2018.

[71] C. M. Djonko-Moore and N. M. Joseph, "Out of the Classroom and Into the City: The Use of Field Trips as an Experiential Learning Tool in Teacher Education,” SAGE Open, Apr. 2016, doi: 10.1177/2158244016649648.

[72] G. Özkan, H. Turan, and U. U. Topsakal, "Opinions of the Sixth Year Students Who Participated in Outdoor Learning Activity Practices for Science," World J. Educ., vol. 10, no. 2, p. 150, 2020.

[73] G. Demircioğlu and A. Aslan, "A Review On Turkish Graduate Studies Performed On Out-Of-School Learning Environments," Karadeniz Teknik Üniversitesi Sosyal Bilimler Enstitüsü Sosyal Bilimler Dergisi, vol. 8, no. 16, pp. 379-402, 2018.

[74] L. Tuuling, T. Õu, and A. Ugaste, "Teachers' opinions on utilizing outdoor learning in the preschools of Estonia," J. Adventure Educ. Outdoor Learn., vol. 19, no. 4, pp. 358-370, 2019.

[75] M. Kalogiannakis, G. M. Nirgianaki, and S. Papadakis, "Teaching Magnetism to Preschool Children: The Effectiveness of Picture Story Reading," Early Child. Educ. J., vol. 46, no. 5, pp. 535-546, 2018.

[76] E. Suryawati and K. Osman, "Contextual Learning: Innovative Approach towards the Development of Students' Scientific Attitude and Natural Science Performance," Eurasia J. Math. Sci. Technol. Educ., vol. 14, no. 1, pp. 61-76, 2017.

[77] S. Glaab and T. Heyne, "Focus wildlife park: Outdoor learning at workstations for primary school children," Appl. Environ. Educ. Commun., vol. 19, no. 2, pp. 141-154, 2020.

[78] İ. N. Altintas and Ç. K. Yenigül, "Active learning education in museum," Int. J. Eval. Res. Educ. (IJERE), vol. 9, no. 1 , pp. $120-128,2020$.

[79] M. Kalogiannakis, M. Ampartzaki, S. Papadakis, and E. Skaraki, "Teaching natural science concepts to young children with mobile devices and hands-on activities. A case study," Int. J. Teach. Case Stud., vol. 9, no. 2, p. 171, 2018.

[80] M. Kalogiannakis and S. Papadakis, "Evaluating Pre-service Kindergarten Teachers' Intention to Adopt and Use Tablets Into Teaching Practice for Natural Sciences," Int. J. Mob. Learn. Organ., vol. 13, no. 1, pp. 113-127, 2019.

[81] P. Dorouka, S. Papadakis, and M. Kalogiannakis, "Tablets and Apps for Promoting Robotics, Mathematics, STEM Education and Literacy in Early Childhood Education," Int. J. Mob. Learn. Organ., vol. 14, no. 2, pp. 255-274, 2020 . 